\title{
A cross-sectional analysis of investigator needs for non-communicable disease research at the University of the West Indies, Mona
}

\author{
Georgia A Williamson ${ }^{1}$, Shelly Rodrigo ${ }^{2}$, Natalie Guthrie-Dixon', Elizabeth Blackman ${ }^{3}, J$ Robert Beck ${ }^{3}$, \\ Ian Hambleton ${ }^{4}$, Althea Bailey ${ }^{5}$, Tomlin Paul ${ }^{6}$, Camille C Ragin ${ }^{3}$, Marshall K Tulloch-Reid ${ }^{1}$
}

Suggested citation Williamson GA, Rodrigo S, Guthrie-Dixon N, Blackman E, Beck JR, Hambleton I et al. A cross-sectional analysis of investigator needs for non-communicable disease research at the University of the West Indies, Mona. Rev Panam Salud Publica. 2021;45:e35. https://doi.org/10.26633/RPSP.2021.35

ABSTRACT Objective. To describe the needs of academic staff conducting non-communicable disease (NCD) research at the University of the West Indies, Mona Campus in Jamaica.

Methods. Utilizing a cross-sectional design an online survey was created using the research electronic data capture application (REDCap); it was disseminated via email to 708 academic staff members in the Faculties of Medical Sciences and Science \& Technology between September and November 2018. Participants were asked to indicate their level of access to expertise, training and equipment for conducting research. Descriptive analysis was conducted using STATA version 14.

Results. Most respondents were women $(74.2 \%)$, predominantly scientists $(33.1 \%)$ or specialist physicians (22.6\%). Less than $2 / 3$ of respondents reported publishing research findings in peer reviewed journals, with a quarter not disseminating their research findings in any medium. Resources for field research/data collection, epidemiological methods and principles, and data management/data analysis were generally available. However, there was limited access to training, expertise and equipment in emerging techniques for NCD research such as metabolomics, bioinformatics/analysis of large-scale data sets and health economics. Additional challenges included limited access to financing for research, inadequate workspace and poor administrative support for conducting research.

Conclusions. There is a need for more local research seed funding, stronger administrative support for researchers, and opportunities for training in cutting edge NCD research techniques. Jamaican researchers could benefit from being part of a regional research centre of excellence with critical research skills and equipment that builds research networks and strengthens the NCD research response.

Keywords Developing countries; health research agenda; noncommunicable diseases; Jamaica; Caribbean Region.

Seventy five percent $(75.0 \%)$ of all deaths and $35.0 \%$ of preventable deaths in the Caribbean region are attributed to non-communicable diseases (NCDs) (1). In the Caribbean, locally driven research has been less than adequate in responding to the NCD burden affecting countries. The shortage of investigators and access to resources and training may be key reasons for the region's inability to proactively address the NCD epidemic (2).

\footnotetext{
Caribbean Institute for Health Research at The University of the West Indies (UWI), Mona, Jamaica $₫$ Marshall Tulloch-Reid, marshall.tullochreid@uwimona. edu.jm

2 Caribbean Public Health Agency, Trinidad and Tobago
}

\footnotetext{
3 Fox Chase Cancer Center, Philadelphia, United States of America 4 Caribbean Institute for Health Research at UWI, Cave Hill, Barbados 5 Department of Community Health and Psychiatry at UWI, Mona, Jamaica 6 Faculty of Medical Sciences at UWI, Mona, Jamaica
} 
Countries with low research capacity and output are at a disadvantage as they lack the ability to generate and use data for planning and the creation of new ideas to advance socially and economically (3). Because disease burden and impact are influenced by socio-demographic, cultural and environmental factors, it is important to investigate any disease in diverse settings to improve our understanding of its aetiology, prevention and control. It is therefore critical for low and middle income countries (LMICs) and small island developing states (SIDS) which share a higher NCD burden, to be actively conducting research for dealing with these conditions (4).

Additionally, LMICs and SIDS have small economies with increased vulnerability to natural disasters and climate change, have low workforce capacity and limited research infrastructure (5). Investigators in these countries have less dedicated time for scientific research due to competing responsibilities including teaching and providing clinical care or consultancy services. Additionally, access to funding and mentorship are key challenges that hinder high quality research output (6). These LMICs as well as SIDS struggle to create a research environment that will capture data on their local situation and provide evidence for policy and action (4). Disparities in research output have become more pronounced over the last decade and while there have been some improvements in research output from LMICs, there is a considerable disparity with high income countries (HICs) (4).

In a review of published abstracts presented at the Caribbean Public Health Agency (CARPHA)(7) Meetings, most of the research consisted of surveys and simple observational studies, and not analytical studies or clinical trials that provide stronger evidence for policy. The University of the West Indies (UWI), in collaboration with the Fox Chase Cancer Center (FCCC) and the African Caribbean Cancer Consortium (AC3), was recently awarded a Planning Grant by the National Cancer Institute (NCI) to develop a Regional Centre for Research Excellence (RCRE) to help address the Caribbean's NCD research needs. As part of this process we wanted to understand the challenges that regional researchers face in relation to NCD research.

In this paper we assessed the needs of academic staff conducting non-communicable disease research at the UWI, Mona Campus in Jamaica, a middle-income small island developing state (SIDS).

\section{METHODS}

The UWI is a regional Caribbean University serving over 18 English Speaking countries and territories (predominantly SIDS). Mona is the UWI's first campus and the site of the largest Faculty of Medical Sciences with significant capacity for both basic science and clinical research. The Faculty of Science and Technology has several departments which overlap with the Faculty of Medical Sciences -particularly in basic science research- and so research capacity in this Faculty would also be of interest in the NCD response.

\section{Study design}

We conducted a cross-sectional, self-administered survey on NCD research needs among academic and research staff at the UWI, Mona between September and November 2018. All academic staff from the Faculties of Science \& Technology and Medical Sciences were identified through the office of the Campus Registrar and a list provided to the researchers.

The list consisted of UWI email addresses for 708 staff members who were sent an invitation to participate in the survey. Deans and relevant Heads of Department from each of the two faculties, were sensitized about the survey through emails and phone calls, and were asked to promote the survey among staff. Potential survey respondents also received email alerts two weeks prior to the circulation of the survey that provided a summary of the research objectives and the participants' role.

\section{Eligibility criteria}

Persons were eligible to participate in the study if they were full-time academic staff and had a UWI email in either of the two faculties. Academic staff included lecturers, professional staff (e.g. laboratory staff) and research assistants.

\section{Survey instrument}

The research electronic data capture (REDCap) software was used to create the online data collection instrument. The survey was piloted among regional academic staff and modifications were made based on respondents, and investigators, review.

The thematic areas for the questionnaire were guided by parallel projects previously conducted in other regions around the world, and questions were adopted from three needs assessment tools. The first had been used by the Health Information and Research Unit, Ministry of Health, Bahamas in an analysis of their national health research system. The other two tools were acquired from RCREs needs assessments conducted in India and Zimbabwe that had been supported under the same NCI Planning grant mechanism (8).

The data collection instrument had 4 main sections:

1. Participant Demographics: education/training, academic role \& classification

2. Previous and current research activities including disease focus, funding sources, grant administration, dissemination, collaborative networks

3. Access to expertise, training and equipment in the following areas: laboratory research, oncology research and care, cardiology research and care, data management \& analysis, field research/data collection, health systems/economics, scientific communication

4. Perception of the research environment: access to funding, research policy environment, staffing, ability to collaborate, access to literature, publishing resources.

To reduce respondents' burden, sections on access to expertise, training and equipment were provided as prompts for completion only if applicable to respondents' area of work.

\section{Data collection}

The survey was disseminated through the REDCap platform to all 708 email addresses from a UWI email that is used for official announcements to prevent it being rejected as spam. Respondents had the option to communicate with the project investigators via this master email or directly to the lead 
investigator. The REDcap interface provided current updates on the status of each survey, that allowed for weekly reminders to be sent to respondents up to the close of the survey.

The survey was live for three months. Once commenced, each respondent was provided with a unique code linked to their email address which would allow them to access their survey responses. The option to save and return later to complete the questionnaire was linked to the code. The project team was able to provide these access codes in case respondents forgot or lost access to this code. Participants responses were entered directly, into the electronic database.

\section{Analysis}

Data were exported to STATA version 14 for analysis (College Park, TX). Data from all questionnaires were used in the analysis, including those that were partially completed. Descriptive statistics of participants' responses are presented according to the main questionnaire themes. Subgroup analysis was limited by the poor response rate.

\section{Ethical aspects}

This study was approved by the FCCC's Institutional Review Board (IRB). In addition, permission to approach the Faculty Members to participate in this study was obtained from the University Registrar for the Mona Campus. Respondents were informed of their autonomy to participate in the survey and their right to withdraw at any time through email correspondence. Consent was implied by their decision to complete the questionnaire.

\section{RESULTS}

The staff email list provided had over 200 inactive mailboxes as a significant proportion of the staff may have been using alternate email addresses that we did not have access to. A total of 124 persons responded to the survey. Of these respondents, only 59 provided complete responses. All data provided by respondents were used when available.

\section{Demographic characteristics}

The characteristics of the respondents are presented in Table 1 . The majority were female faculty members $(74.2 \%)$. Approximately a third (33.1\%) were non-clinician scientists, $22.6 \%$ specialist physicians and $16.9 \%$ clinicians including nurses, pharmacists or physiotherapists. Most (65.8\%) had a master's or higher-level degrees, with the majority (> $46.1 \%)$ getting their terminal degree within the last decade. Over a third $(34.5 \%)$ of the respondents spent more than half of their work time on research, while over $20.0 \%$ indicated research activities consumed more than $50 \%$ of their private time.

\section{Research activities and output}

While over $61.4 \%$ of respondents reported that their research had been published in peer-reviewed journals, about a quarter had not disseminated the findings from their research in any medium. The majority $(79.0 \%)$ of current research activities were new projects. Approximately $50 \%$ of those reporting
TABLE 1. Characteristics of survey respondents from UWI, 2018

\begin{tabular}{|c|c|c|}
\hline Category & Frequency $(n)$ & $\%$ \\
\hline \multicolumn{3}{|l|}{$\operatorname{Sex}(N=124)$} \\
\hline Males & 32 & 25.8 \\
\hline \multicolumn{3}{|l|}{ Self-Reported Employment Category ( $\mathrm{N}=124)$} \\
\hline Physician, specialist & 28 & 22.6 \\
\hline General practitioner & 1 & 0.8 \\
\hline Physician, scientist & 10 & 8.1 \\
\hline Clinician (non-physician e.g. nurse/pharmacist) & 21 & 16.9 \\
\hline Scientist (non-clinician) & 41 & 33.1 \\
\hline Other & 23 & 18.6 \\
\hline \multicolumn{3}{|l|}{ Education achievement $(\mathrm{N}=120)$} \\
\hline Postgraduate or doctoral degree & 52 & 43.3 \\
\hline Professional university based degree & 34 & 28.3 \\
\hline Master's degree & 27 & 22.5 \\
\hline Other & 7 & 5.8 \\
\hline \multicolumn{3}{|l|}{ Year Degree awarded (N=115) } \\
\hline $1980-2000$ & 22 & 19.1 \\
\hline $2000-2009$ & 40 & 34.8 \\
\hline $2010-2018$ & 53 & 46.1 \\
\hline \multicolumn{3}{|l|}{ Time spent on research $(\mathrm{N}=115)$} \\
\hline At workplace & 21 & 36.2 \\
\hline$<20 \%$ & 17 & 29.3 \\
\hline$\leq 50 \%$ & 20 & 34.5 \\
\hline \multicolumn{3}{|l|}{$>50 \%$} \\
\hline \multicolumn{3}{|l|}{ Private time } \\
\hline$<20 \%$ & 23 & 41.8 \\
\hline$\leq 50 \%$ & 21 & 47.2 \\
\hline$>50 \%$ & 11 & 20.0 \\
\hline \multicolumn{3}{|l|}{ Findings Dissemination $(\mathrm{N}=57$ ) } \\
\hline Presentation at institution & 36 & 63.2 \\
\hline Presentation outside institution & 33 & 57.9 \\
\hline Local peer-reviewed journal & 6 & 10.5 \\
\hline Regional peer-reviewed journal & 1 & 1.8 \\
\hline International peer-reviewed journal & 28 & 49.1 \\
\hline Book & 2 & 3.5 \\
\hline \multicolumn{3}{|l|}{ Current Research Area $(\mathrm{N}=53)$} \\
\hline Clinical & 15 & 28.3 \\
\hline Epidemiological & 12 & 22.6 \\
\hline Basic & 10 & 18.9 \\
\hline Behavioral & 7 & 13.2 \\
\hline Other & 7 & 13.1 \\
\hline
\end{tabular}

current studies were in the areas of clinical or epidemiological research.

\section{Lab and clinical expertise}

Participants indicated that they had access to expertise in most areas of laboratory research except for metabolomics (Table 2). They also reported limited access to training and facilities requiring this approach to analysis. Expertise in oncology and cardiology was adequate and accessible, however, access to training and specialist equipment particularly in palliative care and radiotherapy were low (results not shown). 
TABLE 2. Proportion of respondents indicating access to expertise, training and laboratory research and data management, 2018

\begin{tabular}{|c|c|c|c|}
\hline & $\begin{array}{l}\text { Expertise } \\
n(\%)\end{array}$ & $\begin{array}{l}\text { Training } \\
\mathrm{n}(\%)\end{array}$ & $\begin{array}{l}\text { Equipment } \\
\mathrm{n}(\%)\end{array}$ \\
\hline \multicolumn{4}{|l|}{ Laboratory research $(\mathrm{N}=24)$} \\
\hline Metabolomics & $3(12.5)$ & $1(4.2)$ & $4(16.7)$ \\
\hline Genetics & $10(41.7)$ & $4(16.7)$ & $6(25.0)$ \\
\hline Molecular biology & $17(68.0)$ & $5(20.0)$ & $11(45.8)$ \\
\hline Cell biology & $11(45.8)$ & $4(16.7)$ & $6(25.0)$ \\
\hline Biochemistry & $22(88.0)$ & $11(44.0)$ & $9(36.0)$ \\
\hline Animal studies & $13(52.0)$ & $8(32.0)$ & $9(36.0)$ \\
\hline Natural products research & $14(58.3)$ & $10(41.7)$ & $11(45.8)$ \\
\hline \multicolumn{4}{|l|}{$\begin{array}{l}\text { Data management/data } \\
\text { analysis }(\mathrm{N}=50)\end{array}$} \\
\hline $\begin{array}{l}\text { Database development/ } \\
\text { maintenance }\end{array}$ & $22(44.0)$ & $16(32.0)$ & $18(36.0)$ \\
\hline Basic statistical analysis & $46(92.0)$ & $36(72.0)$ & $41(82.0)$ \\
\hline Advanced statistical analysis & $30(60.0)$ & $18(36.0)$ & $27(54.0)$ \\
\hline $\begin{array}{l}\text { Bioinformatics and large } \\
\text { datasets }\end{array}$ & $9(18.0)$ & $4(8.0)$ & $3(6.0)$ \\
\hline
\end{tabular}

\section{Research expertise}

Most respondents reported adequate access to expertise, training and equipment in field research/data collection, epidemiological methods \& principles and scientific communication (Table 3). However, access to expertise and training in health systems/economics was low. Another under-resourced area was database development/maintenance and analysis for bioinformatics and large-scale datasets.

\section{Perception of research environment}

Overall, perception of the research environment by the respondents was poor (Table 4). Most persons indicated that there was little funding for research despite a belief that this was being used to shape health policy. They felt that enough local research was not being performed. They also had challenges identifying adequate sources of local funding and were not aware of a clear national research agenda. Workspace and facilities to conduct health research were inadequate. Nevertheless, most respondents believed that they were adequately trained to conduct health research and that forums for discussing, disseminating and publishing of findings were adequate. Research collaborations were actively encouraged, and seminars, mentorship and research group meetings were a part of routine activities taking place within their departments.

\section{DISCUSSION}

Most respondents had experience conducting research in areas such as natural/biological sciences, medical/clinical sciences, population/public health, and health systems/ policy/services but had limited access to cutting edge NCD techniques and equipment. Additional local or seed funds for research, improved research infrastructure, stronger research
TABLE 3. Proportion of respondents indicating access to expertise and training for field research, health systems research, epidemiological methods and scientific communication, 2018

\begin{tabular}{|c|c|c|}
\hline & $\begin{array}{c}\text { Expertise } \\
n(\%)\end{array}$ & $\begin{array}{c}\text { Training } \\
\mathrm{n}(\%)\end{array}$ \\
\hline \multicolumn{3}{|l|}{ Field research /data collection ( $\mathrm{N}=39$ ) } \\
\hline Subject recruitment/retention & $26(66.7)$ & $22(56.4)$ \\
\hline Development of data collection instrument & $30(76.9)$ & $22(56.4)$ \\
\hline Acquisition and processing of samples & $28(71.8)$ & $23(59.0)$ \\
\hline \multicolumn{3}{|l|}{ Health systems/economics ( $N=19)$} \\
\hline Health policy & $7(36.8)$ & $2(11.8)$ \\
\hline Programme, planning and evaluation & $10(52.6)$ & $5(29.4)$ \\
\hline Implementation science & $8(42.1)$ & $5(29.4)$ \\
\hline Health services delivery & $8(42.1)$ & $3(17.6)$ \\
\hline Health economics & $2(10.5)$ & $2(11.8)$ \\
\hline \multicolumn{3}{|c|}{ Epidemiological methods and principles $(\mathrm{N}=36$ ) } \\
\hline Surveillance and descriptive epidemiology & $28(77.8)$ & $23(63.9)$ \\
\hline Epidemiologic study design & $29(80.6)$ & $26(72.2)$ \\
\hline Systematic reviews and meta-analysis & $20(55.6)$ & $18(51.4)$ \\
\hline \multicolumn{3}{|l|}{ Scientific communication ( $N=42)$} \\
\hline Grant/proposal writing & $32(76.2)$ & $18(42.9)$ \\
\hline Manuscript preparation & $32(76.2)$ & $23(54.8)$ \\
\hline Oral presentation & $38(90.5)$ & $26(61.9)$ \\
\hline Poster presentation & $34(81.0)$ & $20(47.6)$ \\
\hline
\end{tabular}

administrative support and a more systematic approach to the communication and dissemination of local research findings were critical needs that limited the NCD research response.

Despite improvements in the expertise for research in developing regions through research partnerships in the last 2 decades (9), there is need for more research examining risk factors for disease and associated disparities (10). While expertise in clinical aspects of care and epidemiological research for NCD were readily available, proficiency in other critical areas that are important to responding to the NCD epidemic (metabolomics, large scale datasets, data management) were not readily available and opportunities for training and capacity building were limited. Other areas that required strengthening were in health systems research and health economics.

\section{Financing}

Inadequate research funding was an unmet need reported by investigators in this survey, consistent with reports from other LMICs $(10,11)$. Limited administrative support for grant preparation and management, unsatisfactory workspace and limited access to key journals also result from this restricted access to research funding. A recent report by the Department for International Development (DFID) recommended that funding for research should take a holistic approach that targets the individual, institutions and research environment for sustainable capacity building in low resourced setting (10). Research success can generate additional funding for more research and help build the required research infrastructure and support systems.

The publication of research findings is critical for improving access to competitive international funding opportunities, 
TABLE 4. Perception of research environment by respondents at the UWI, 2018

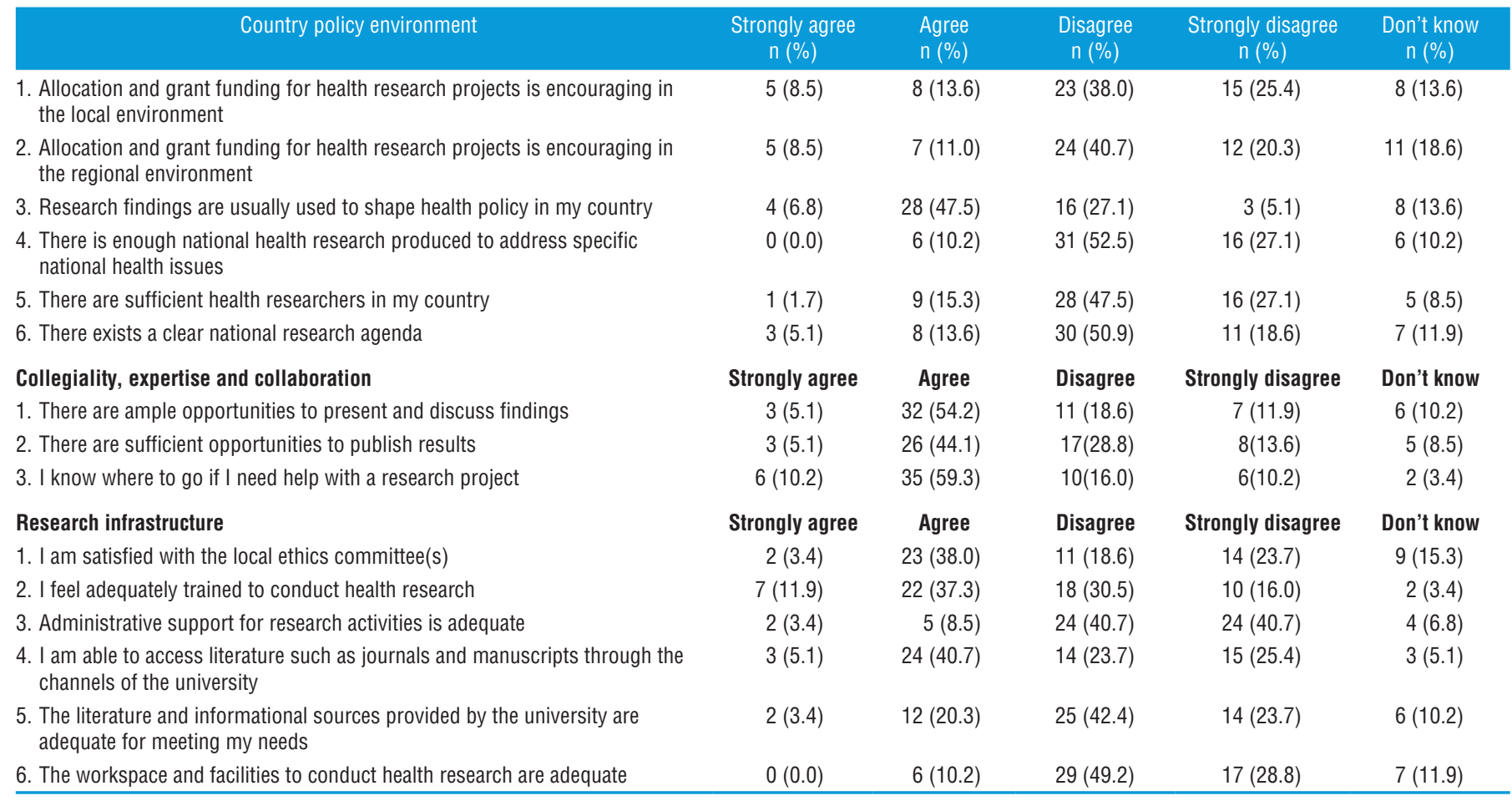

identifying research partners and incorporating these findings into policy. While most of the published research at UWI were in global peer reviewed journals, one in four research projects conducted by the investigators sampled were not published. Competing routine activities may hinder investigators from greater participation in publishing research. The absence of a publishing culture, rejection anxiety and awareness of journals have also been identified as barriers to publishing for investigators in low resourced settings (12). Limited funding for publication charges may also be an inhibiting factor. Globally, LMIC investigators continue to be underrepresented in published literature (13). Prioritizing funding to foster research culture and providing resources for participation at international research conferences may increase motivation for publishing (10).

\section{Local research}

Investigators believed that there is not a clear national research agenda and that there is not enough local research to address national health problems. This assessment of the national research landscape speaks to the challenges within the current environment to meet the needs of stakeholders, which are consistent across the Caribbean (14). A government lead research agenda can facilitate prioritizing of research needs, advocates for partnerships and buy in from stakeholders to promote meaningful change $(11,15,16)$. Jamaica for instance, though the Ministry of Health and Wellness has an essential national health committee that prioritizes research areas, has advocated for seed funding for graduate students at each of the islands major universities and recently launched a J\$50.0M fund to find solutions to problems in public health $(17,18)$. However, this is not always feasible in SIDSs where resource allocation for research is not readily available.

\section{Mentorship and training}

There is no structured mentorship programme for academic staff within the UWI (19). Mentorship is a tool of transformation that guides individuals at varying stages of career development in achieving full potential (20), and provides sustainable human resource for continued participation in research. Currently, most mentorship takes place through graduate programmes between supervisors and graduate students (19) but there are limited opportunities for post-doctoral fellowships and guidance support for new faculty. Mentorship in this critical window sets the stage for a successful research career.

Respondents indicated that a considerable amount of time was spent outside of work on research activities. This may suggest that there are competing demands on time due to teaching or administration commitments, or inadequate access to academic and administrative support staff, requiring that they utilize personal time to meet their research targets. Intervention on research needs and capacity among health professionals from India and Nepal found that research is seen as an integral part of education and career advancement; however, this was threatened by restrictions in training and mentorship (4). Other research enhancement activities highlighted by respondents are facilitated at the department/unit level, illustrating the need for an organizational driven research culture that will generate activities and programmes for mentorship/training of both staff and students for a sustainable research future. 
Partnerships between HICs and LMICs have been forged to strengthen the fight against modern day public health challenges. Access to funding, knowledge/skills transfer, resource development, fellowships, scholarships, mentorships and other training opportunities have been made available to new and seasoned investigators from LMIC across Asia and Africa $(21,22)$. These collaborations/partnerships have proven effective over the years as they have aided in the strengthening of local research culture and the production of research output that are locally relevant (23).

\section{Research collaboration}

There has been a global push to improve research capacity in developing regions by providing opportunities for training, infrastructure modernization and acquisition of tools through partnerships that will expand the landscape for locally driven research in these countries. An example of this is the UWI partnership with FCCC and the African Caribbean Cancer Consortium (AC3) that has culminated this 13 years collaboration in cancer research between UWI, other regional partners and HICs investigators has resulted in numerous Caribbean-led research outputs (24-27). The solidification of this partnership through this NCI-funded award has furthered opportunity for training and research enhancement, through exchange visits for grants administration, laboratory and pathology training, as well as opportunities to mentor early stage UWI investigators in the preparation of NIH career development grant applications. Additionally, the Faculty of Medical Sciences at the UWI, Mona has over the past 5 years developed a partnership with the State University of New York (SUNY) which has so far generated resources for training and research in infectious diseases. The NCDs are also on the agenda for this collaboration. The Harvard Bernard Lown Scholarship programme also provides opportunities for researchers in developing countries to advance their skills through training in research for cardiovascular disease prevention. This programme provides small grants for undertaking research in the home country of the awarded individuals (28). Thus, contributing to the production of indigenous research that is key to building the evidence based for policy and planning. Investigators from the UWI have also benefited from this scholarship programme. Other examples of individual scientist awards include the 'Career Development Programme' between the World Health Organization and $\mathrm{NIH}$, and the Emerging Global Leader Award Program offered through the NIH Fogarty International Centre $(23,29)$.

While partnerships and collaborative relationships initiated by global institutions have operated for over half a century in LMICs. The need to strengthen the participant home institutions to absorb and utilize these skills as well as sustain these interventions is also a critical aspect of capacity building that should not be ignored (9). Other factors that impact motivation for research engagement among faculty, and academics such as terms of employment, appraisal and reward systems can dampen the impact of capacity building interventions if not addressed.

\section{Limitations}

One of the main limitations of this study was the poor response rate. Competing interests may have contributed to the poor response rate as it was conducted during the first semester of the academic year; however, participants had up to 3 months to attempt the survey. In addition, there is a possibility of response bias with active researchers more likely to answer the survey. This may have resulted in overestimation of the skills and research enhancement activities that are taking place in the University. Finally, respondents may have felt the survey was too lengthy leading to a lot of incomplete responses; however, these challenges are not unique to online surveys. Further exploration of some of these issues with key informant interviews and focus groups among faculty members may be helpful in addressing some of these concerns and identifying possible solutions.

\section{Recommendations}

The social accountability framework should be used to develop a research enterprise through partnerships with academia, government and non-governmental agencies to address the priority health needs of society (30). In addition, developing strategic relations with ministries of health and other stakeholders in the region is key to the creation of a framework that will directly address the human resource deficiencies in regional scientific research. Prioritizing career development programmes, scholarships and grants for postgraduate training locally and with internationally recognised institutions, should be pursued to increase competency and sustainability in critical areas. Other efforts to lobby regional governments and build strategic partnerships with the private sector (medical insurance, pharmaceutical industry, health care delivery and medical diagnostics) to strengthen research should be encouraged. Finally, assessments are needed to determine the state of research infrastructure, tools and equipment to increase the potential for more sophisticated studies and increase research output for responding to local and regional NCD challenges.

\section{Conclusion}

Our findings suggest that LMIC investigators are faced with several challenges that affect their NCD-related research output. In addition to funding, there is a need to support the research infrastructure including stronger administrative support, protected research time, physical research space and equipment, and access to training and specialist resources. The UWI provides an opportunity for advancing the research milieu as the cadre of faculty and existing resources can be harnessed to strengthen regional NCD response. We believe a Centre of Research Excellence mindful of current research needs can provide regional methodological and laboratory support. This may be a cost-effective approach to strengthen the UWI Mona Campus and, in turn, the regional response to the NCD epidemic.

Authors contributions. CR, JRB and MTR conceived and planned the study. GW, SR, NGD, EB, CR and MTR designed the instrument. GW, NGD and MTR collected, analysed and interpreted the data. GW and MTR wrote the paper, with editing and reviewing by all authors. All authors reviewed and approved the final version.

Acknowledgements. The authors thank the survey respondents, and the Health Information and Research Unit, Ministry of Health, Bahamas (Drs. Camille S. Nairn, Donald Simeon 
and Ms.Nanika Brathwaite-Clarke) and Dr. Morton Anthony Frankson from the UWI, Bahamas for facilitating the adaption of their national tool for use in this study. We also thank the Office of the Campus Registrar and members of the African Caribbean Cancer Consortium (AC3) for their support in the execution of this survey.

Funding. This study was supported in part by Grant 5P20CA219204 to MTR, CR, JRB and AB as well as Grant
CCSGCA006927 to JRB. The sponsors did not influence any aspect of this research design, collection, analysis, writing, or decision to publish these results.

\section{Conflicts of interests. None declared.}

Disclaimer. Authors hold sole responsibility for the views expressed in the manuscript, which may not necessarily reflect the opinion or policy of the RPSP/PAJPH and/or PAHO.

\section{REFERENCES}

1. WHO. Non-communicable diseases in the Americas: Quick facts and figures. In: PAHO, editor. WHO; 2015. p. 2.

2. Engelgau MM, Sampson UK, Rabadan-Diehl C, Smith R, Miranda J, Bloomfield GS, et al. Tackling NCD in LMIC: Achievements and Lessons Learned From the NHLBI-UnitedHealth Global Health Centers of Excellence Program. Global Heart. 2016;11(1):5-15.

3. Dianis NL, Wolbach TL, Spiegelman M. The NHLBI-UnitedHealth Global Health Centers of Excellence Program: Assessment of Impact of Federal Funding Through a Social Network Analysis. Global Heart. 2016;11(1):145.

4. Varadaraj V, Ranjit A, Nwadiuko J, Canner J, Diener-West M, Schneider EB, et al. Towards diaspora-driven research capacity strengthening in low- and middle-income countries: results from India and Nepal. International Health. 2018:ihy076-ihy.

5. Kaser M, Maure C, Halpaap BM, Vahedi M, Yamaka S, Launois P, et al. Research Capacity Strengthening in Low and Middle Income Countries - An Evaluation of the WHO/TDR Career Development Fellowship Programme. PLoS Negl Trop Dis. 2016;10(5):e0004631.

6. Bloomfield GS, Xavier D, Belis D, Alam D, Davis P, Prabhakaran D, et al. Training and capacity building in LMIC for research in heart and lung diseases: the NHLBI-UnitedHealth Global Health centers of excellence program. Global Heart. 2016;11(1):17-25.

7. Williamson GR, S. Ragin, CC. Blackman, E. Beck, JR. Tulloch-Reid, MK. An evaluation of regional cardiovascular disease and cancer research needs using conference abstracts. 64th Annual CARPHA Health Research Conference 201919 June 2019; Trinidad \& Tobago. West Indian Med J. 2019;68:1-84; p. 79.

8. NIH. CGH Announces Recipients of Regional Centers of Research Excellence (RCREs) P20 Grant Awards; 2016.

9. Tulloch-Reid MK, Saravia NG, Dennis RJ, Jaramillo A, Cuervo LG, Walker SP, et al. Strengthening institutional capacity for equitable health research: lessons from Latin America and the Caribbean. BMJ (Clinical research ed). 2018;362:k2456.

10. Conalogue DM, Kinn S, Mulligan J-A, McNeil M. International consultation on long-term global health research priorities, research capacity and research uptake in developing countries. Health Res Pol Syst. 2017;15(1):24.

11. Bowsher G, Papamichail A, El Achi N, Ekzayez A, Roberts B, Sullivan $\mathrm{R}$, et al. A narrative review of health research capacity strengthening in low and middle-income countries: lessons for conflict-affected areas. Glob Health. 2019;15(1):23.

12. Sumathipala A, Siribaddana S, Patel V. Under-representation of developing countries in the research literature: ethical issues arising from a survey of five leading medical journals. BMC Medical Ethics. 2004;5(1):5.

13. Iyer AR. Authorship trends in the Lancet global health. Lancet Glob Health. 2018;6(2):e142.

14. Murphy MM, Unwin N, Samuels T, Hassell TA, Bishop L, Guell C. Evaluating policy responses to noncommunicable diseases in seven Caribbean countries: challenges to addressing unhealthy diets and physical inactivity. Rev Panam Salud Publica. 2019;42:e174.

15. Hassell T, Hennis A. Chronic disease challenges in the Caribbean. Global Heart. 2016;11(4).

16. Anauati MV, Galiani S, Weinschelbaum F. The rise of noncommunicable diseases in Latin America and the Caribbean: challenges for public health policies. Lat Am Econ Rev. 2015;24(1):11.
17. MOH. \$50M Available for Wellness Research: Ministry of Health and Wellness; 2019 [cited 2019 Dec 2019]. Available from: https:// www.moh.gov.jm/50m-available-for-wellness-research/.

18. Angus GL. Health Minister Encourages Researchers To Utilise Fund Online: Jamaica Information Service 2019 [Available from: https: / / jis.gov.jm/health-minister-encourages-researchers-to-utilise-fund/.

19. UWI. Annual Report 2018-2019 Maximizing Our Resources for a Sustainable Future. The University of the West Indies; 2019.

20. Hamer DH, Hansoti B, Prabhakaran D, Huffman MD, Nxumalo N, Fox MP, et al. Global health research mentoring competencies for individuals and institutions in low-and middle-income countries. Am J Trop Med Hyg. 2019;100(1_Suppl):15-9.

21. Minja H, Nsanzabana C, Maure C, Hoffmann A, Rumisha S, Ogundahunsi $\mathrm{O}$, et al. Impact of health research capacity strengthening in low- and middle-income countries: the case of WHO/TDR programmes. PLoS Negl Trop Dis. 2011;5(10):e1351.

22. Mensah GA. Training in Cardiovascular Epidemiology and Prevention: A 50-Year Journey From Makarska to Goa. Global Heart. 2018;13(4):355-62.

23. Dean L, Njelesani J, Smith H, Bates I. Promoting sustainable research partnerships: a mixed-method evaluation of a United Kingdom-Africa capacity strengthening award scheme. Health Res Pol Syst. 2015;13:81.

24. Foster K, Younger N, Aiken W, Brady-West D, Delgoda R. Reliance on medicinal plant therapy among cancer patients in Jamaica. Cancer Causes Control. 2017;28(11):1349-56.

25. Tulloch-Reid MK, McFarlane-Anderson N, Bennett FI, Aiken WD, Jackson MD. Effects of cholesterol, C-reactive protein, and interleukin-6 on prostate cancer risk in a population of African ancestry. Cancer Causes Control. 2017;28(11):1313-21.

26. Ragin C, Blackman E, Roberts R, Butler R, Gathere S, Halliday D, et al. Cancer in populations of African Ancestry: studies of the African Caribbean Cancer Consortium. Springer; 2017.

27. Gibson TN, McNaughton DP, Hanchard B. Sinonasal malignancies: incidence and histological distribution in Jamaica, 1973-2007. Cancer Causes Control. 2017;28(11):1219-25.

28. HLS. The Bernard Lown Scholars in Cardiovascular Health Program Online: Harvard College; 2019 [cited 2019 November 20]. Available from: https:/ /www.hsph.harvard.edu/lownscholars/.

29. NIH. Fogarty allocates $\$ 4 \mathrm{M}$ to support early-career scientists Online Fogarty International Center 2020 [cited 20202 November 2020]. Volume 19, Number 5:[Available from: https://www.fic. nih.gov/News/GlobalHealthMatters/september-october-2020/ Pages/emerging-global-leader-k43-awards.aspx?utm_medium= email\&utm_campaign $=$ ghm\&utm_source $=$ ghm2020october.

30. Boelen C, Woollard R. Social accountability: the extra leap to excellence for educational institutions. Med Teach. 2011;33(8):614-9.

Manuscript received on 24 August 2020; revised version accepted for publication on 9 November 2020. 


\section{Análisis transversal de las necesidades de los investigadores de las enfermedades no transmisibles en la Universidad de las Indias Occidentales en Mona}

RESUMEN Objetivo. Describir las necesidades del personal académico que investiga las enfermedades no transmisibles (ENT) en el Campus de Mona de la Universidad de las Indias Occidentales, en Jamaica.

Métodos. Mediante un diseño transversal, se elaboró una encuesta en línea con RedCap, una aplicación para la captura de datos electrónicos para la investigación, y se divulgó por correo electrónico a los 708 miembros del personal académico de las Facultades de Ciencias Médicas y Ciencia y Tecnología entre septiembre y noviembre del 2018. Se pidió a los participantes que indicaran su nivel de acceso a conocimientos, capacitación y equipo para llevar a cabo investigaciones. El análisis descriptivo se realizó con STATA, versión 14.

Resultados. La mayoría de los entrevistados fueron mujeres (74,2\%), predominantemente científicas (33,1\%) o médicas especialistas (22,6\%). Menos de dos terceras partes de los entrevistados informó que publicaban los resultados de sus investigaciones en revistas arbitradas y una cuarta parte declaró que no divulgaba los resultados de sus investigaciones en ningún medio. Por lo general, tenían a su disposición recursos para la investigación de campo o la recopilación de datos, métodos y principios epidemiológicos, así como para la gestión y el análisis de datos. Sin embargo, tenían poco acceso a conocimientos, capacitación y equipo en las técnicas emergentes para la investigación sobre ENT como la metabolómica, la bioinformática o el análisis de conjuntos de datos a gran escala y economía de la salud. Otros retos incluyeron poco acceso al financiamiento para la investigación, espacios de trabajo inadecuados y un apoyo administrativo deficiente para investigar.

Conclusiones. Se necesita más capital inicial destinado a la investigación local, un mayor respaldo administrativo a los investigadores y oportunidades de capacitación en las técnicas más recientes de investigación de ENT. Los investigadores jamaiquinos podrían sacar provecho de formar parte de un centro regional de excelencia para la investigación con el equipo y las capacidades de investigación fundamentales para contribuir a la formación de redes de investigación y fortalecer la respuesta investigadora a las ENT.

Palabras claves

Países en desarrollo; agenda de investigación en salud; enfermedades no transmisibles; Jamaica; Región del Caribe. 


\section{Uma análise transversal das carências dos pesquisadores envolvidos em pesquisa de doenças não transmissíveis na Universidade das Índias Ocidentais, Mona}

RESUMO Objetivo. Descrever as carências enfrentadas pelo grupo acadêmico que realiza pesquisa em doenças não transmissíveis (DNT) na Universidade das Índias Ocidentais, campus de Mona, Jamaica.

Métodos. Uma pesquisa transversal online foi desenvolvida com o uso da plataforma de captura eletrônica de dados de pesquisa (RedCap) e distribuída por e-mail a 708 integrantes dos grupos acadêmicos nas Faculdades de Ciências Médicas e de Ciência e Tecnologia entre setembro e novembro de 2018. Foi pedido aos participantes que informassem o grau de acesso a conhecimento especializado, capacitação e equipamentos para a realização de pesquisa. Uma análise descritiva foi realizada com o uso do software STATA versão 14.

Resultados. Participaram, na sua maioria, mulheres $(74,2 \%)$, com o predomínio de pesquisadores científicos $(33,1 \%)$ ou médicos especialistas (22,6\%). Menos de 2/3 informaram publicar os resultados de suas pesquisas em periódicos científicos com avaliação por pares e $25 \%$ disseram que não divulgavam seus resultados em nenhum veículo. Afirmaram que, em geral, havia recursos para realizar pesquisa de campo/coleta de dados, métodos e procedimentos básicos epidemiológicos e gerenciamento/análise de dados. Porém, era limitado o acesso a capacitação, conhecimentos especializados e equipamentos para empregar métodos emergentes de pesquisa de DNT como metabolômica, bioinformática/processamento em larga escala de grandes conjuntos de dados e economia da saúde. Outras dificuldades citadas foram limitação de financiamento para pesquisa, inadequação dos locais de trabalho e apoio administrativo deficiente à realização de pesquisas.

Conclusões. Faz-se necessário mais financiamento para projetos iniciantes locais, firme apoio administrativo aos pesquisadores e oportunidades para capacitação em métodos de ponta de pesquisa de DNT. A situação dos pesquisadores jamaicanos poderia melhorar se fizessem parte de um centro de excelência regional com recursos e equipamentos essenciais para a realização de pesquisa que lhes permitisse formar redes de pesquisadores e fortalecer a resposta da pesquisa de DNT.

Palavras-chave

Países em desenvolvimento; Agenda de pesquisa em saúde; doenças não transmissíveis; Jamaica; Região do Caribe. 